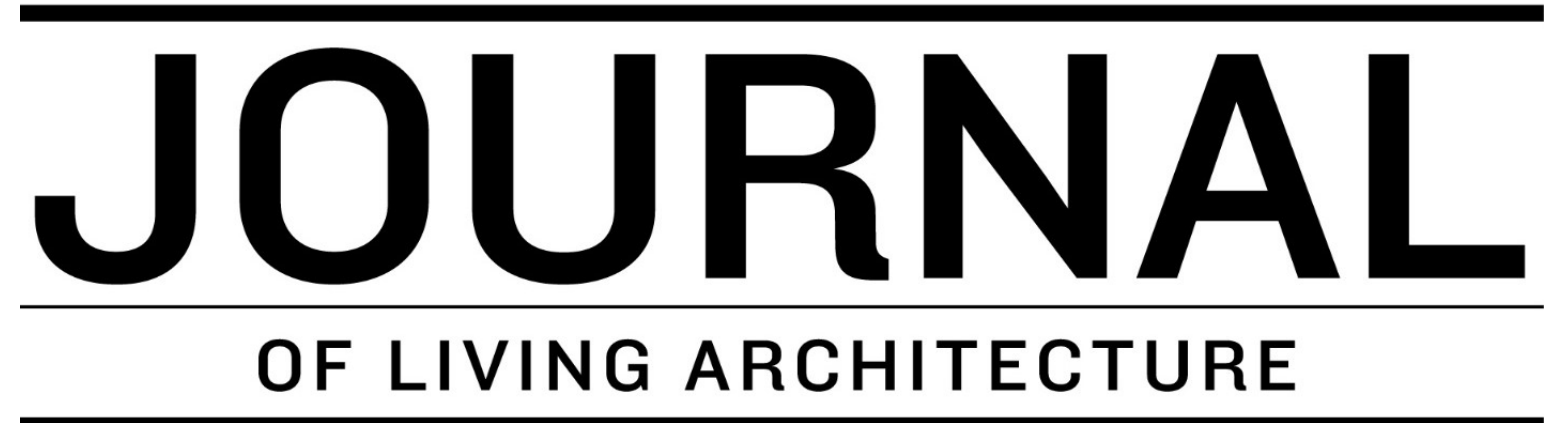

A GREEN ROOFS FOR HEALTHY CITIES PUBLICATION

Volume 6 Number 1 Pages 31-43

2019

\title{
Plant performance with and without nutrient addition on a low-maintenance green roof in New England
}

\author{
Lauren Healey $^{1}$, Peter Alpert ${ }^{1^{*}}$, Michael Ea ${ }^{1}$ \\ ${ }^{1}$ Biology Department, University of Massachusetts - Amherst \\ *corresponding author: palpert@bio.umass.edu
}

\begin{abstract}
Little research is available on green roofs in the harsh New England climate. Performance of 12 plant species and effects of adding soil nutrients were measured on an established green roof in central Massachusetts over two growing seasons, starting when maintenance ended, two years after planting. Sedum hybridum plus ellacombianum maintained about $60 \%$ cover where planted and reached 50\% cover elsewhere. Other species had $0-10 \%$ cover. Volunteer species combined had up to $60 \%$ cover, bringing totals to $70-90 \%$. Nutrients had little effect. Low-maintenance green roofs appear feasible in New England, but species should be locally pre-tested. Volunteers may enhance performance.
\end{abstract}

Key words: green roof, low maintenance, New England, Sedum hybridum, soil nutrient addition 


\section{INTRODUCTION}

Although the North American green roof market is growing, it is hindered by a lack of information on plant performance (Dvorak and Volder 2010). For example, the industry currently relies largely on European guidelines for plant selection (Breuning and Yanders 2008). This operates on the potentially false assumption that the same plants that thrive on European green roofs will also thrive in North America (Monterusso et al. 2005; Dvorak and Volder 2010). Research has started to document the success of some widely used species of Sedum in North America, particularly in the Midwest (Monterusso et al. 2005; Rowe et al. 2006; Snodgrass and Snodgrass 2006; Dunnett and Kingsbury 2008; Whittinghill et al. 2016). However, only a few studies have been conducted on green roofs in New England (Licht and Lundholm 2006; Butler and Orians 2011), where the seasonally cold, highly variable climate may reduce the performance of species used on green roofs elsewhere. One objective of this study is to add to the knowledge of species' performance in the New England climate that is needed for development of green roofs in this region of North America.

The green roof industry in North America has also largely adopted the low-maintenance regimen common in Europe, which often includes little or no addition of soil nutrients beyond the amounts in the original planting substrate (Breuning and Yanders 2008). Several studies have shown that varieties of Sedum do respond positively to additions of slow- or controlled-release fertilizer in northern climates during the production (Vinson and Zheng 2013; Clark and Zheng 2014a) and establishment periods (Barker and Lubell 2012; Clark and Zheng 2012, 2014b; Vinson and Zheng 2013). There is preliminary evidence that addition of fertilizer is not necessary for the growth of some plants after the establishment period in some climates in North America (Rowe et al. 2006; Clark and Zheng 2013), though species grown as crops may benefit from additions (Ouellette et al. 2013; Whittinghill et al. 2016). Moreover, unnecessary fertilization could increase susceptibility to winter damage (Smith and Kaurin 1989) and risk of downstream water contamination (Rowe et al. 2006). However, no published study appears to have tested effects of nutrient addition to an established green roof in a climate comparable to that of New England. Annual addition of slow-release fertilizer imposes a very modest maintenance burden, and it could promote the growth of the green roof industry to better understand the potential benefits of limited maintenance. The second objective of this study was therefore to test whether addition of slow-release soil fertilizer can increase plant performance on established green roofs in New England.

\section{METHODS}

\section{Study area}

Research was conducted on the green roof of the four-storey Integrated Learning Center (ILC) at the University of Massachusetts in Amherst, Massachusetts, about $160 \mathrm{~km}$ west of Boston. Mean daily minimum and maximum temperatures in Amherst vary from $-11^{\circ} \mathrm{C}$ and $1^{\circ} \mathrm{C}$ in January to $15^{\circ} \mathrm{C}$ and $28^{\circ} \mathrm{C}$ in July (NOAA 2018). The main growing season, based on mean last and first frost days, extends from May 13 to September 30. Mean annual 
precipitation is $117 \mathrm{~cm}$, with little variation between months except that much of the precipitation during December through March falls as snow.

The ILC green roof was planted in the fall of 2014 and covers $1394 \mathrm{~m}^{2}$ (University of Massachusetts - Amherst 2012; Figure 1). The roof was constructed using a typical built-up green roof construction of roof decking, protection board, insulation, protection mat, drainage mat, filter sheet, lightweight substrate with a depth of $15.2 \mathrm{~cm}$, and plant cover. The substrate was a commercial blend of Garick calcined clay and superhumus (rooflite ${ }^{\circledR}$, Skyline USA, Langenberg, Pennsylvania, USA; Paul Muller, personal communication). Eight drains were spread throughout the roof.

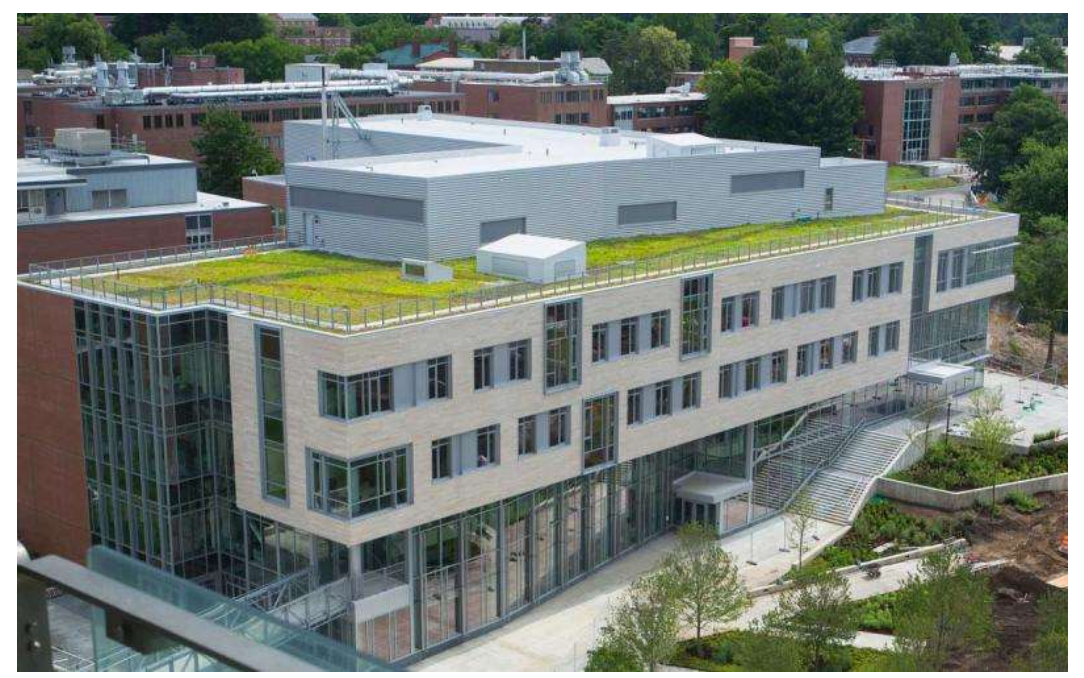

Figure 1 The green roof on the Integrated Learning Center at the University of Massachusetts Amherst. Photo courtesy of the University of Massachusetts - Amherst Facilities Department.

The roof was planted with four mixtures of species, referred to as planting types, arranged in a mosaic of polygons separated by aluminum edging (Figure 2). Two of the planting types, Sedum A and Sedum B, were mixtures of species of Sedum installed as pre-vegetated mats. Sedum A consisted of Sedum acre "Aureum", S. ellacombianum, S. hybridum "Czar's Gold" and "Immergrunchen", S. reflexum "Green Spruce", S. rupestre "Angelina", and S. spurium "Green Mantle". Sedum B consisted of Sedum album "Coral Carpet", S. sexangulare, S. spurium "Coccineum", "Fuldaglut", and "Voodoo", S. sieboldii, and S. stefco. The species and varieties of Sedum were chosen for their hardiness and performance and to create contrasting areas of red and green foliage; information on initial proportions of species within mixtures could not be found. The other two planting types, Carex and Festuca, were monocultures of the sedge Carex pennsylvanica and the grass Festuca glauca "Elijah blue" planted as $10-\mathrm{cm}$-diameter plugs at a density of $16.5 \mathrm{plants} / \mathrm{m}^{2}$. These two species were chosen to test their suitability for use on New England green roofs and for aesthetics. The substrate was amended with biochar for these two planting types (Paul Muller, personal communication). 


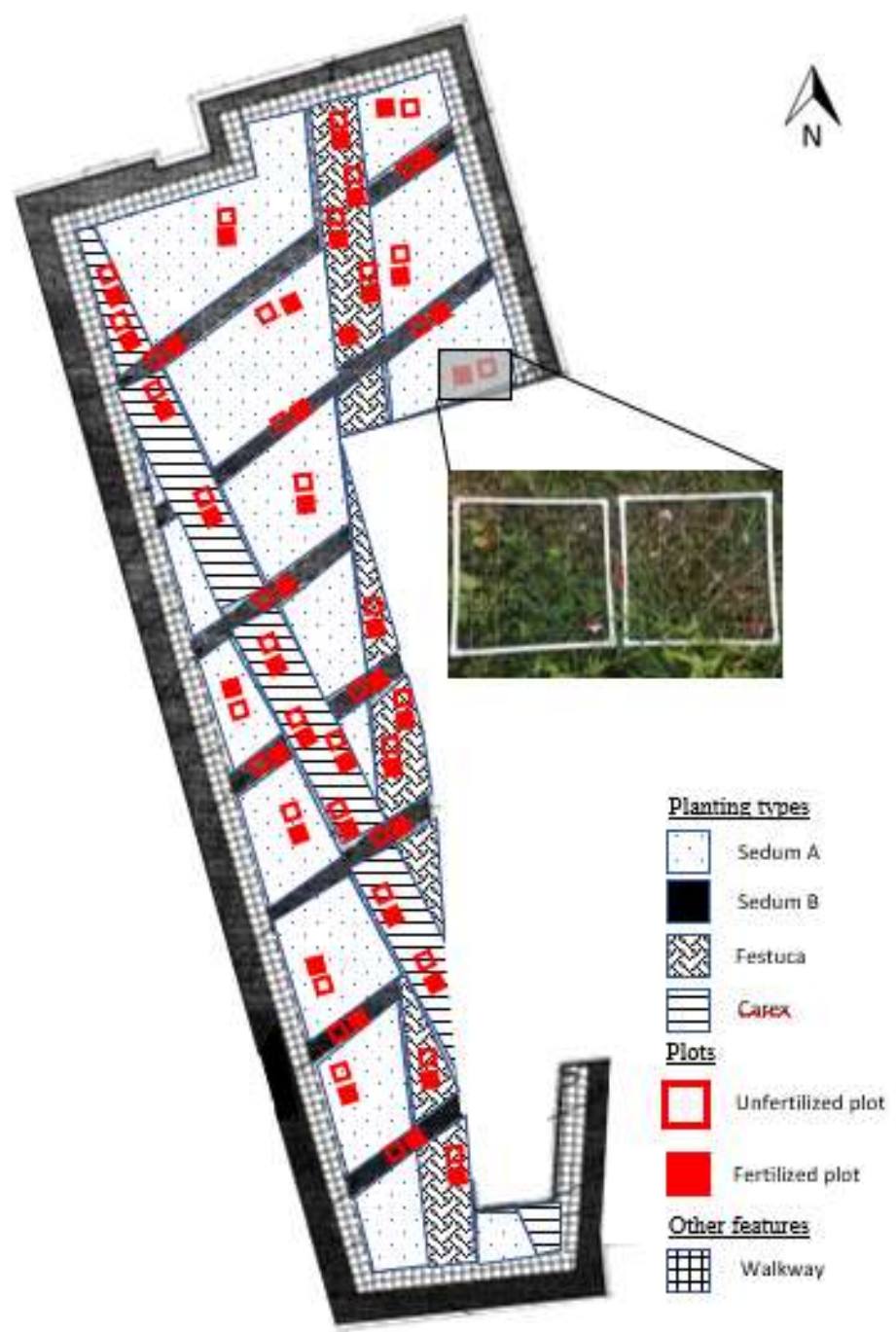

Figure 2 Planting and sampling scheme. Blow-up shows a photo of one pair of plots; frames were placed around plots only during measurements and nutrient additions. Modified from the Integrated Learning Center Green Roof Plan and Details, Drawing Number L004, Facilities Department, University of Massachusetts, Amherst.

During installation in the fall of 2014 and over the first growing season in 2015, plantings were irrigated to aid establishment. From installation through the second growing season in 2016, volunteer species (i.e., those not planted on the roof), mainly Trifolium pratense, Plantago major, and grasses (Poaceae), were removed by hand pulling and, in the cases of Cyperus esculentus and C. rotundus, by spraying with halosulfuronas in the form of SedgeHammer ${ }^{\mathrm{TM}}$ (Gary Glazier and Charlie Sinkler, personal communications). Over this maintenance period, from 2014-2016, plantings had an informally estimated mean total cover of over $80 \%$ (Gary Glazier, personal communication). Starting in 2017, the roof was virtually unmaintained. There appear to have been no rigorous measurements of plant cover made before the present study. 


\section{Experimental design}

To quantify plant performance under the new, low-maintenance regime on the roof and to test whether addition of soil nutrients as slow-release fertilizer would increase performance, plant species cover was measured over two growing seasons in plots with and without added nutrients, using a stratified random, paired plot design (Figure 2). Ten pairs of 50 x 50 plots $25 \mathrm{~cm}$ apart were located in each of the four planting types by first allocating pairs among the polygons of a given type in proportion to polygon size and then locating pairs randomly within a given polygon. Five levels of nutrient addition were each randomly assigned to two of the 10 pairs in each planting type. Levels were amounts of the slow-release fertilizer Osmocote ${ }^{\mathrm{TM}}$ Bloom (2-3 month release; $5.3 \% \mathrm{~N}$ as $\mathrm{NO}_{3}, 6.7 \% \mathrm{~N}$ as $\mathrm{NH}_{4}, 7 \% \mathrm{P}^{2}$ as $\mathrm{P}_{2} \mathrm{O}_{5}, 18 \%$ $\mathrm{K}$ as $\mathrm{K}_{2} \mathrm{O}$; www.everris.com) that provided 5, 10, 15, 20, or $25 \mathrm{~g} \mathrm{~N} / \mathrm{m}^{2}$. Levels were chosen based on Clark and Zheng (2014a) and correspondence with the manufacturer. In each pair of plots, one randomly chosen plot received added nutrients, and the other plot received no treatment. Nutrients were added on April 18 and September 19, 2017, and on April 21, 2018.

Performance was measured visually as percent cover of each species in each plot, using a 10 $\mathrm{x} 10 \mathrm{~cm}$ grid and the cover classes $0-1,1-5,5-10,10-15$, etc. This method has proven as accurate as recording species presence at points (Kolb et al. 2002). It was not possible to reliably distinguish cultivars within species or to distinguish the two species of Sedum with broad, spirally arranged leaves, S. hybridum and S. ellacombianum, whose cover is therefore presented together. Cover was measured before the start of the main growing season and near peak cover for the growing season in 2017 and 2018, on April 5-18 and September 8-19, 2017; and April 5-20 and September 9-19, 2018. Initial cover did not differ between plots within pairs in any planting type for any species (paired $t$-tests: each $p>0.1$ ). As a backup, a photograph of each plot was taken at each time of measurement.

As a rough indication of soil properties at the start of measurements, one soil sample of about $500 \mathrm{~g}$ fresh weight was collected at a depth of 0-10 $\mathrm{cm}$ adjacent to a plot in each planting type on May 4, 2017, and taken to the University of Massachusetts Amherst Soil and Plant Nutrient Testing Laboratory for analysis. Results are presented in supplementary information and show concentrations of total $\mathrm{P}, \mathrm{Mg}, \mathrm{Ca}$, and $\mathrm{K}$ that are considerably higher than those in some other studies (Getter and Rowe 2008; Ouellette et al. 2013; Whittinghill et al. 2016).

Monthly precipitation during the growing season from April through September was similar to mean values for Amherst in 2017 (Figure 3). During 2018, precipitation was only about $40 \%$ of the mean monthly value in May but about 60 to $110 \%$ above mean values in June through September, putting cumulative precipitation during the 2018 growing season well above the mean. Mean daily minimum and maximum air temperatures per month during the growing seasons in 2017 and 2018 were mostly at or $1-3^{\circ} \mathrm{C}$ above mean values (Figure 3). The roof thus did not seem to experience any marked drought or prolonged period of unusual cold or heat likely to affect plant performance during the study. 

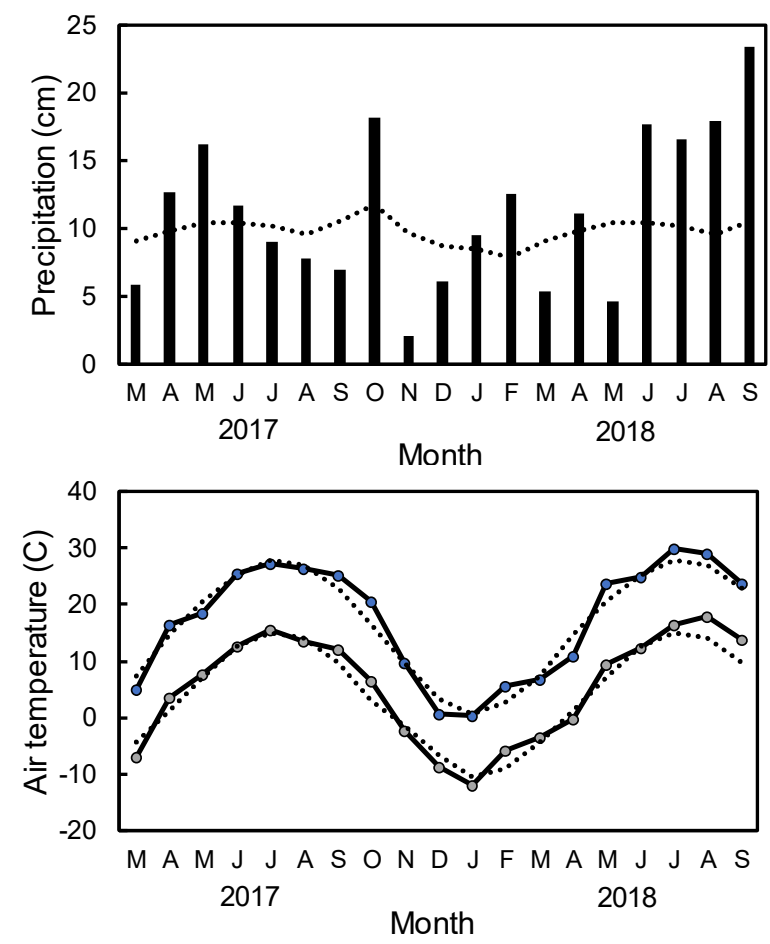

Figure 3 Monthly precipitation and mean daily minimum and maximum air temperature per month in Amherst, Massachusetts $\left(42.39^{\circ} \mathrm{N}, 72.54^{\circ} \mathrm{W}, 44 \mathrm{~m}\right.$ above sea level), during the study period, from March 2017 to September 2018. Dotted lines show mean monthly values for 1981 to 2010. Data are from the National Oceanic and Atmospheric Administration.

\section{Data analysis}

Cover classes were converted to their midpoints before analysis. Change in performance over time without nutrient addition was tested with paired $t$-tests of cover in September 2017 and September 2018. This comparison avoided confounding directional change with seasonal fluctuation, and was preferable to comparing April 2017 and April 2018 because of the relatively low temperatures in April 2018 as noted above. Effect of nutrient addition on performance was tested with linear regression of difference in cover between plots within pairs on level of nutrients added to the fertilized plot in each pair. Regressions based on change in this difference between September 2017 and 2018 gave generally higher values of $\mathrm{R}^{2}$ than regressions based on difference at any one given time and are presented.

\section{RESULTS}

\section{Plant performance without added nutrients}

\section{Change over time}

In the absence of nutrient addition, Sedum A and Sedum B, the two planting types consisting of mixtures of species of Sedum, maintained about an $80 \%$ cover of Sedum and less than $20 \%$ cover of volunteer species and of bare ground plus thatch during 2017, the first growing season with low maintenance (Figure 4). In Sedum B, cover of Sedum was significantly lower by September 2018, the second growing season without maintenance (difference between September 2017 and 2018: $\mathrm{p}<0.05)$. However, cover of volunteers in Sedum B was 
significantly higher in September 2018 than in September 2017, and cover of bare ground remained low, about $10 \%$. The sharp peak in cover of bare ground and thatch in Sedum A in April 2018 corresponded to low temperatures that month (Figure 3).

The monocultures of Carex pennsylvanica and Festuca glauca in planting types Carex and Festuca had completely died by April 2017. However, areas planted with these types were colonized by Sedum from areas planted with Sedum A or B as well as by volunteers (Figure 4). Colonization of the Festuca planting type was relatively slow, but both Carex and Festuca planting types had only about $20 \%$ bare ground or thatch by September 2018 . Volunteers provided about two-thirds of the plant cover in the Festuca type and two-fifths of the plant cover in the Carex type, and showed a significant increase in cover from September 2017 to 2018 in the Carex type. At least 25 species volunteered; a list is given in supplementary information.
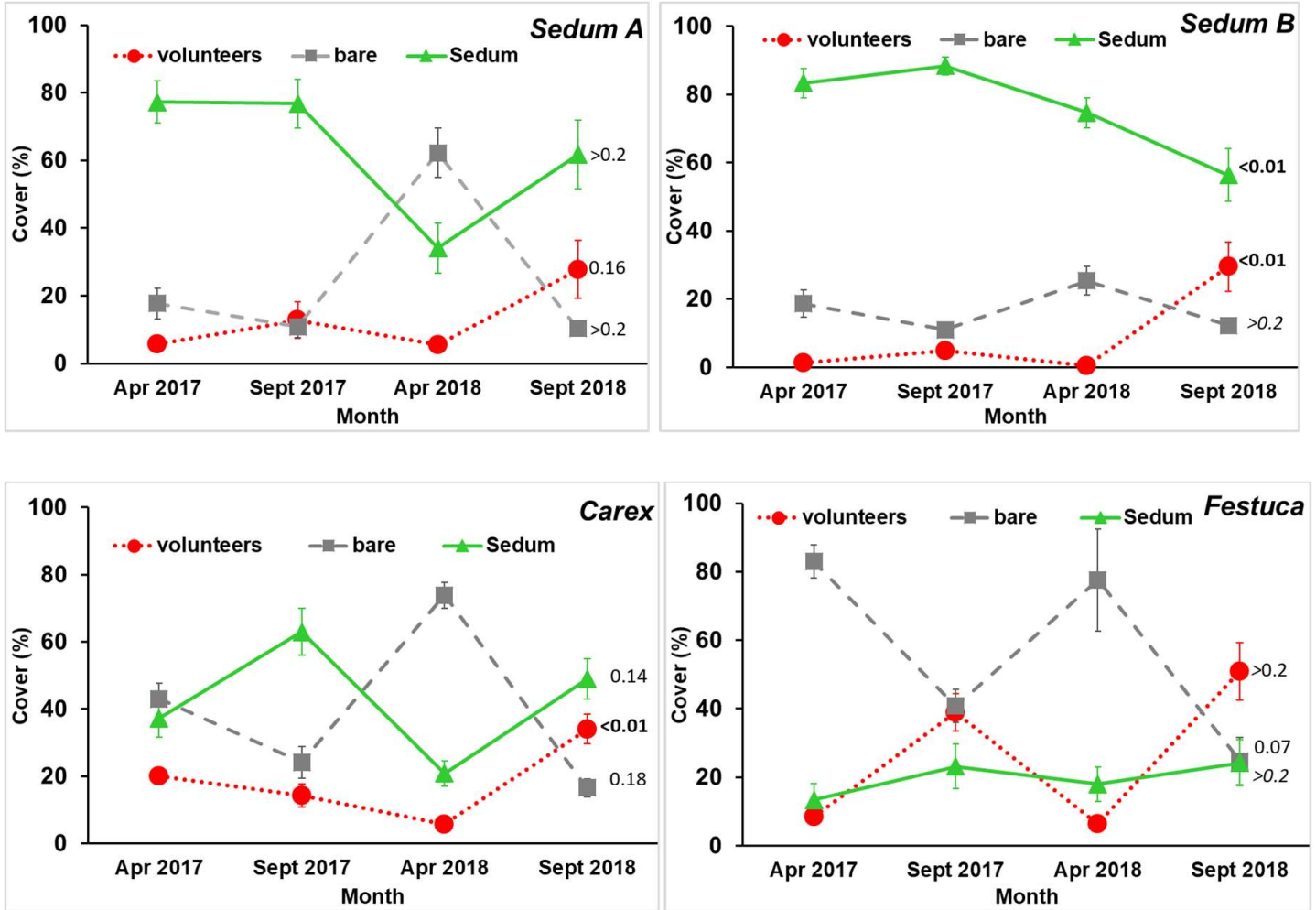

Figure 4 Cover (mean $\pm \mathrm{SE}$ ) of total Sedum, total volunteers, and bare ground (including area covered by thatch) at the start and peak of the growing season in 2017 and 2018 in plots without added nutrients in each of the four planting types. Numerals give probability ( $p$, paired $t$-test, in bold if $<$ 0.05) that means for a given cover category did not differ between September 2017 and September 2018. In some cases, SE was smaller than symbols for means and does not show. 


\section{Final values}

In September 2018, four years after planting and after two years of low maintenance, only one category of Sedum, S. hybridum plus ellacombianum, had a cover greater than $10 \%$ in any planting type (Figure 5). These species covered $60 \%$ of Sedum A, where they were planted, and $10-50 \%$ of each type in which they were not planted. They accounted for about $90 \%$ of the cover of Sedum in all types except Festuca. The next most abundant species of Sedum were S. spurium and S. sexangulare, which were present in each type in which they were planted, and in the Carex and Festuca types. Three of the 10 planted species of Sedum were not found. Bare ground excluding thatch covered about $25 \%$ cover in the Festuca type but $10 \%$ or less in other types. Cover data by species for earlier measurement times are in supplementary information.
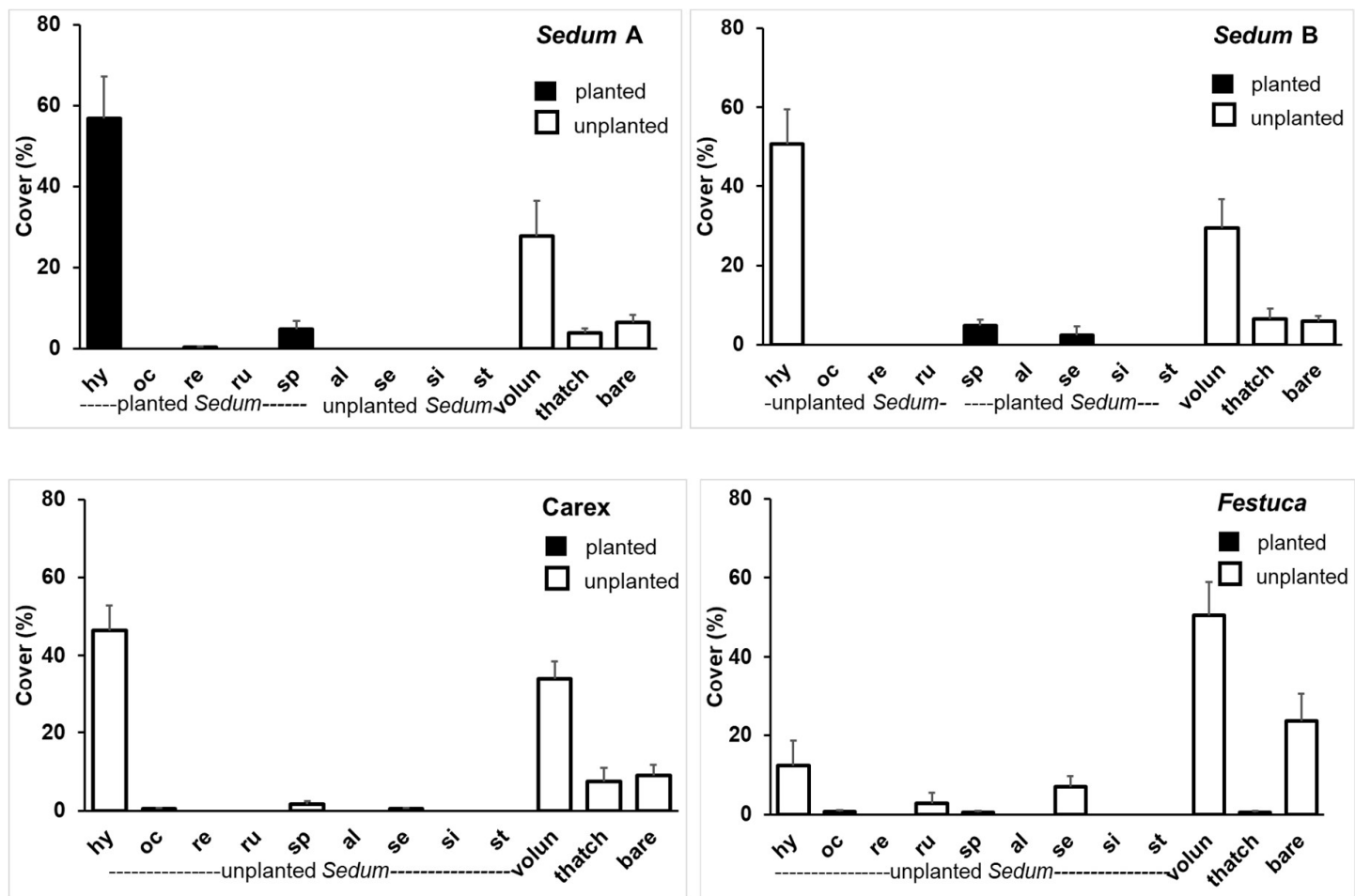

Figure 5 Cover (mean + SE) in plots without added nutrients in September 2018. Abbreviations: hy Sedum hybridum plus ellacombianum, oc $-S$. ochroleucum, re $-S$. reflexum, ru $-S$. rupestre, $\mathrm{sp}-S$. spurium, al - S. album, se - S. sexangulare, si - S. sieboldii, st - S. stefco, volun - volunteers.

\section{Effects of nutrient addition on plant performance}

Addition of soil nutrients had little effect on cover of either Sedum or volunteers in the different planting types as measured by change in the difference in cover between paired plots from September 2017 to September 2018 (Figure 6). The strongest relationship between cover and nutrient addition was a marginally significant decrease in cover of Sedum with increasing nutrients in the Sedum B type. Cover of Sedum or volunteers showed no consistent tendency to decrease, increase, or peak with nutrient addition in different planting types. Nutrient addition likewise showed little effect on cover of Sedum or volunteers as measured 
in preliminary analyses based on change in the difference in cover between paired plots over other periods such as April 2017 to April 2018, or on the difference between paired plots at a given time.

\section{SEDUMS}

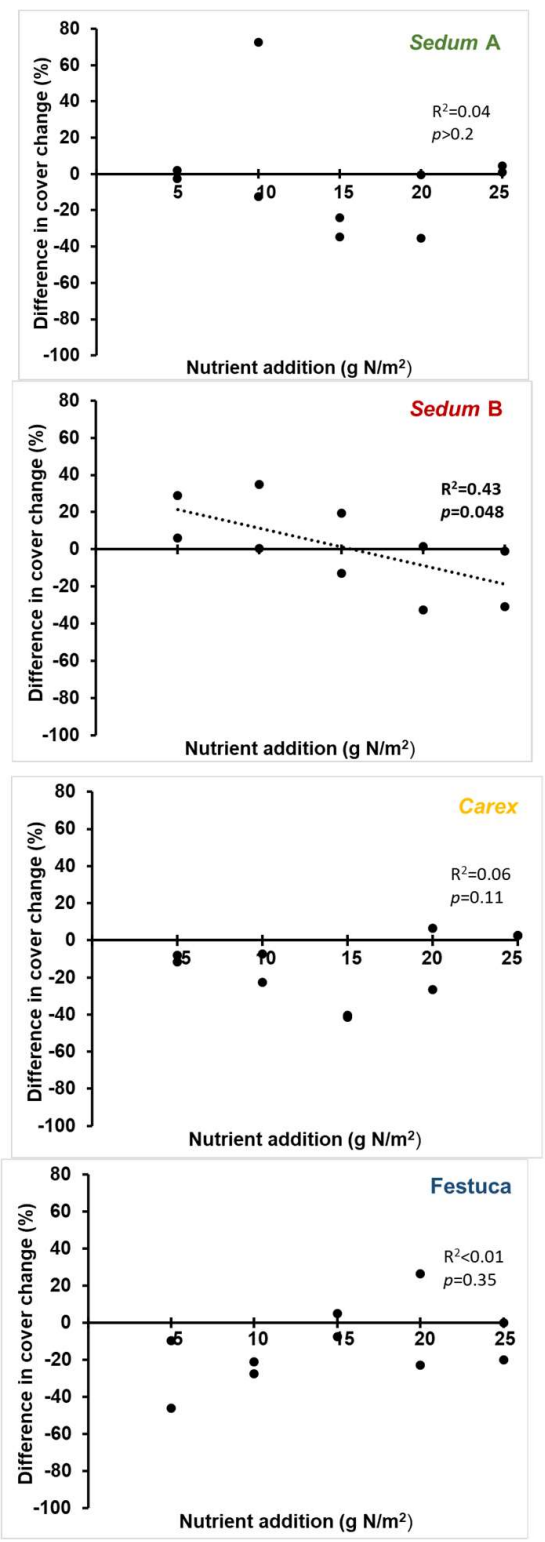

\section{VOLUNTEERS}
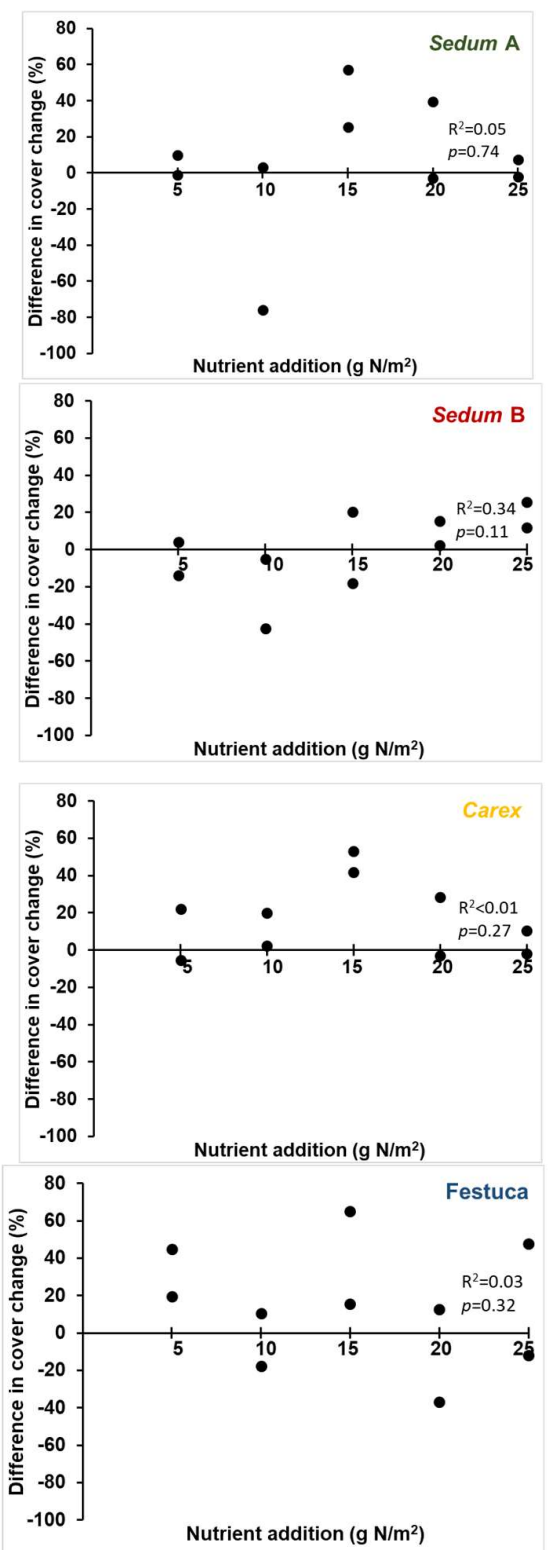

Figure 6 Difference in change in cover from September 2017 to September 2018 between plots given nutrients and paired plots not given nutrients. Results of linear regression of cover on nutrients are given; where $\mathrm{p}<0.05$, the regression line is shown.

\section{DISCUSSION}

As measured by total plant cover, the green roof on the ILC performed well. Four years after installation and two years after the start of a low-maintenance regime, total cover of live plants in the latter part of the growing season was just over the typical warranty standard of at least $80 \%$ cover in three of the four planting types. In the other planting type, total cover was 
about $70 \%$ despite complete death of the original plants. There was no significant change in the amount of bare ground plus thatch in the latter part of the growing season between the first and second years of low maintenance in any planting type, suggesting that high plant cover might persist in subsequent years. Cover of bare ground plus thatch increased two- to three-fold during the winter between study years, showing that the roof does not necessarily maintain high live plant cover throughout the year. If this is acceptable, then results indicate that low-maintenance green roofs are feasible in New England, at least on comparable roofs in similar subclimates.

On the other hand, few of the individual species planted on the ILC roof performed well. All individuals of the two planted graminoids, Carex pensylvanica and Festuca glauca, had died by the start of measurements. Since both species have been successfully used on other extensive, unirrigated green roofs in other parts of New England (Lubell et al. 2017; Charlie Sinkler, personal communication), it may be that subregional climatic differences can strongly affect their performance. This argues for local pre-testing of species (Brown and Lundholm 2015).

All the species of Sedum were said to have been selected for hardiness. However, no individuals were found of three of the 10 planted species of Sedum at the last measurement time, suggesting that these three species had died completely as well. Only $S$. hybridum or $S$. ellacombianum or both, since these two species were not consistently distinguishable, had mean cover over $30 \%$ in any planting type at any measurement time. Only one other species, S. spurium, had mean cover over $20 \%$ in any type at any time. Getter and Rowe (2008) judged this species suitable for use on roofs in southern Michigan, though they also found $S$. stefco, which apparently died completely on the ILC roof, to be suitable. Other studies in southern Michigan found two of the species that apparently died completely, $S$. acre and $S$. album, to be aggressive spreaders (Monterusso et al. 2005; Rowe et al. 2012). Lack of records of the initial planting densities or cover at installation of the individual species of Sedum used precludes definitively ranking their performance. However, these results again suggest that species need to be specifically tested for survival and growth under low maintenance and local climatic conditions to determine their suitability for use on lowmaintenance green roofs in New England.

Performance of planted species on the roof was greatly enhanced by the evident ability of species of Sedum to spread into areas where they were not originally planted. At least five of the 10 species of Sedum were found in planting types where they were not planted. Unplanted species of Sedum reached about 50\% total cover in two planting types, and about $20 \%$ cover in a third. In each case, S. hybridum plus ellacombianum made up most of the total. These results highlight an advantage of planting clonal species that spread laterally by stolons or rhizomes: poor performance of one species may be compensated by spread of another (Monterusso et al. 2005).

Volunteer species, those not planted in any planting type on the roof, substantially enhanced performance as measured by total live plant cover. Volunteers made up one-fourth to two- 
thirds of the total cover in the four planting types by the end of measurements. Cover of volunteers increased or remained constant over the last year of measurements in each planting type, suggesting that they might reach higher cover in subsequent years. Volunteers also contributed greatly to species diversity, adding at least 25 species, including at least 8 native species, to the 7 surviving planted species. Nagase et al. (2013) similarly noted the contribution of volunteer, native species to diversity on a semi-extensive roof in the UK. Dunnett et al. (2008) counted 35 volunteer species over four years on another roof in the UK, although 5 of the species together accounted for about three-fourths of the total density of volunteers. Volunteers may also contribute to the long-term resilience of green roofs; as a result of species turnover during 27 years on an extensive roof in Germany, species composition shifted from northern and central towards southern European and from relatively competitive to more ruderal and then more stress-tolerant species (Catalano et al. 2016).

Concern about overreliance on a few genera such as Sedum has been one reason for directing research towards incorporating native plants into green roof design (Sutton et al. 2012; Vinson and Zheng 2013). Volunteers, whether native to a region or introduced, are often regarded as weeds to eradicate from green roofs; and some species, such as introduced species that crowd out natives, are probably undesirable (Nagase et al. 2013). However, the successful volunteer species on the ILC roof have clearly demonstrated that they can survive and grow on a low-maintenance roof in New England. Allowing some colonization by volunteers could thus help to create a more robust and diverse list of species for planting on green roofs in northern climates (Lubell et al. 2017).

It seems notable that the Festuca and Carex planting types had less than $20 \%$ cover of volunteers in April 2017 despite having a large amount of bare ground and thatch. Possible explanations are that thatch left by dead plants prevented colonization by seed, that Carex and Festuca served as placeholders against volunteers until their death, and that the herbicide used against some volunteers in the first two years prevented weed growth into the third year, when leaching diluted herbicides enough to allow new plant survival and growth. Some evidence for the first explanation comes from the slower colonization of the Festuca type, which had higher cover of thatch. If this explanation is correct, then planting species that produce ample, persistent thatch might discourage volunteers when this is desired.

There was no indication that addition of slow-release fertilizer increased cover of Sedum or of volunteers. The lack of effect of soil fertilizer on plant performance was not likely due to insufficient amounts, since some of the levels used were relatively high compared to those in other studies (Rowe et al. 2006; Clark and Zheng 2014b; Whittinghill et al. 2016), and there was no tendency for cover to increase with amount of nutrients added. This suggests that nutrient addition may not be necessary on established, low-maintenance roofs in climates like those in central Massachusetts. This will of course depend upon the nutrient levels in the original planting substrate, which may have been relatively high on the ILC roof. Results from a two-year study also cannot rule out the possibility of longer term effects of continued nutrient addition. 


\section{RECOMMENDATIONS}

The industry should continue to expand the use of low-maintenance green roofs in New England. Species for planting should be pre-tested for ability to survive and grow with low maintenance in the local climate, and this could be a focus of research. Use of species that spread vegetatively may help compensate for poor performance of other species. Sedum hybridum or ellacombianum and S. spurium appear to be successful species that spread quickly and should be strongly considered for planting on extensive green roofs in New England. Depending upon the original planting substrate used, soil nutrient addition may not improve plant performance on established, low-maintenance green roofs in New England, especially roofs planted with Sedum.

It may be in the best interests of the green roof industry in New England to embrace volunteer species. Such roofs may have high diversity and low requirements for maintenance, and still meet suggested cover standards. However, volunteers may include unattractive species (Dunnett et al. 2008), and their widespread acceptance will be contingent on aesthetic values.

\section{ACKNOWLEDGEMENTS}

We thank Samantha Gallagher for assistance with data collection and analysis, and Pamela Monn, Jeff Quakenbush, Michael Kauffman, and the University of Massachusetts - Amherst Facilities Department for providing information and access to the green roof on the Integrated Learning Center. Research was supported by a Maureen Flanagan Scholarship.

\section{LITERATURE CITED}

Barker, K. J., and Lubell, J. D. 2012. "Effects of species proportions and fertility on Sedum green roof modules." HortTechnology 2: 196-200.

Breuning, J., and Yanders, A. 2008. Introduction to the FLL Guidelines for the Planning, Construction and Maintenance of Green Roofing. Green Roof Service, LLC, Baltimore, Maryland.

Brown, C., and Lundholm, J. 2015. "Microclimate and substrate depth influence green roof plant community dynamics." Landscape and Urban Planning 143:134-142.

Butler, C., and Orians, C.M. 2011. Sedum cools soil and can improve neighboring plant performance during water deficit on a green roof. Ecological Engineering 37:1796-1803.

Catalano, C., Marcenò, C., Laudicina, V.A., and Guarino, R. 2016. "Thirty years unmanaged green roofs: Ecological research and design implications." Landscape and Urban Planning 149:11-19.

Clark, M. J., and Zheng, Y. 2012. "Evaluating fertilizer influence on overwintering survival and growth of Sedum species in a fall-installed green roof." HortScience 12:1775-1781.

Clark, M. J., and Zheng, Y. 2013. "Plant nutrition requirements for an installed Sedum-vegetated green roof module system: effects of fertilizer rate and type on plant growth and leachate nutrient content." HortScience 9:1173-1180.

Clark, M. J., and Zheng, Y. 2014a. "Effect of fertilizer rate on plant growth and leachate nutrient content during production of Sedum-vegetated green roof modules." HortScience 6:819-826.

Clark, M. J., and Zheng, Y. 2014b."Fertilizer rate and type affect Sedum-vegetated green roof mat plant performance and leachate nutrient content." HortScience 3:328-335. 
Dunnett, N., and Kingsbury, N. 2008. Planting Green Roofs and Living Walls. Timber Press, Portland, Oregon.

Dunnett, N., Nagase, A., and Hallam, A. 2008. "The dynamics of planted and colonising species on a green roof over six growing seasons 2001-2006: Influence of substrate depth." Urban Ecosystems 11:373-384.

Dvorak, B., and Volder, A. 2010. "Green roof vegetation for North American ecoregions: A literature review." Landscape and Urban Planning 4:197-213.

Getter, K.L., and Rowe, D.B. 2008. "Media depth influences Sedum green roof establishment." Urban Ecosystems 11:361-372.

Kolb, A., Alpert, P., Enters, D., and Holzapfel, C. 2002. "Patterns of invasion within a grassland community." Journal of Ecology 90:871-881.

Licht, J., and Lundholm, J. 2006. "Native coastal plants for northeastern extensive and semi-intensive green roof trays: substrates, fabrics and plant selection." Fourth Annual Greening Rooftops for Sustainable Communities Conference, May 10-12, Boston, Massachusetts.

Lubell, J., Connolly, B., and Jones, K. 2017. "Ten-year persistence of native plant species on a green roof in the northeast US." Native Plants Journal 18:227-234.

Monterusso, M.A., Rowe, D.B., and Rugh, C.L. 2005. "Establishment and persistence of Sedum spp. and native taxa for green roof applications." HortScience 2:391-396.

Nagase, A., Dunnett, N., and Choi, M.S. 2013. "Investigation of weed phenology in an establishing semi-extensive green roof." Ecological Engineering 58:156-164.

NOAA. 2018. Data Snapshots: Reusable Climate Maps. National Oceanic and Atmospheric Administration [accessed October 1, 2018]. Available from https://www.climate.gov/maps-data.

Ouellette, N., Walters, A., and Midden, K. 2013. "Fertility management for tomato production on an extensive green roof." Journal of Living Architecture 1:1-14.

Rowe, D.B., Getter, K.L, and Durhman, A.K. 2012. "Effect of green roof media depth on Crassulacean plant succession over seven years". Landscape and Urban Planning 104:310-319.

Rowe, D.B., Monterusso, M.A., and Rugh, C.L. 2006. "Assessment of heat-expanded slate and fertility requirements in green roof substrates." HortTechnology 16:471-477.

Smith, J. D., and Kaurin, Å. 1989. "Abiotic overwintering problems of amenity turf grasses." Icelandic Agricultural Sciences 2:25-29.

Snodgrass E., \& Snodgrass L. 2006. Green Roof Plants. Timber Press, Portland, Oregon.

Sutton, R., Harrington, J., Skabelund, L., MacDonagh, P., Coffman, R., and Koch, G. 2012. "Prairiebased green roofs: literature, templates, and analogs." Journal of Green Building 7:143-172.

University of Massachusetts - Amherst. 2012. Section 075570. Document on file in the Facilities Department, University of Massachusetts, Amherst, Massachusetts.

Vinson, K.L., and Zheng, Y. 2013. "Green roof plant suitability analysis for northern climates." HortTechnology 5:563-574.

Whittinghill, L.J., Rowe, D.B., Ngouajio, M., and Cregg, B.M. 2016. "Evaluation of nutrient management and mulching strategies for vegetable production on an extensive green roof." Agroecology and Sustainable Food Systems 40:297-318. 